\title{
The Methylation Profile of IFN- $\gamma$, SOCS1 and SOCS3 Promoter Regions in End-Stage Renal Disease
}

\author{
Maivel Ghattas ${ }^{1}$, Fatma El-shaarawy ${ }^{2}$, Noha Mesbah ${ }^{3}$ and Dina Abo-Elmatty ${ }^{3 *}$ \\ ${ }^{1}$ Department of Medical Biochemistry, Faculty of Medicine, Port Said University, Port said, Egypt \\ ${ }^{2}$ Department of Biochemistry, Faculty of Pharmacy and Pharmaceutical industries, Sinai University, North Sinai, Egypt \\ ${ }^{3}$ Department of Biochemistry, Faculty of Pharmacy, Suez Canal University, Ismailia, Egypt
}

\begin{abstract}
End-stage renal disease (ESRD) is a state of chronic inflammation. DNA methylation is a major epigenetic modification that has the potential to silence gene expression. IFN- $\gamma$ and suppressor of cytokine signaling (SOCS) are essential modulators of inflammation. The current study aimed to determine the methylation status of IFN- $\gamma$, SOCS1 and SOCS3 promoter regions in DNA isolated from peripheral blood of ESRD patients and controls, in order to correlate this methylation status with the clinical features of ESRD. Ninety six ESRD patients and 96 healthy ethnically, age and gender matched controls were included in the study. The promoter methylation of the studied genes was assessed using the methylation-specific polymerase chain reaction (MSP). Most of our samples were positive for IFN- $\gamma$ promoter methylation. Full unmethylation was observed only in the ESRD group (7.3\%), and statistical difference was observed among groups $(P=0.02)$. IFN- $\gamma$ unmethylation was associated to a decrease in estimated glomerular filtration rate (eGFR) and an increase in both serum creatinine and total cholesterol levels. For SOCS1 promoter methylation, partial and full methylation were observed only in ESRD patients (5.2\% and $2.1 \%$, respectively); however no methylation was detected in controls $(P=0.014)$. SOCS3 promoter methylation was not detected in either the patient or control group. In conclusion, the methylation profile of IFN- $\gamma$ and SOCS1 promoter regions play an important role in the pathogenesis of ESRD. The present study highlights the role of epigenetics in disease progression.
\end{abstract}

Keywords: End-stage renal disease; Epigenetics; Interferon gamma; Suppressor of cytokine signaling inflammation

\section{Introduction}

End-stage renal disease (ESRD) patients have been continuous markedly increased morbidity and mortality worldwide despite the development in renal replacement therapy [1]. In Egypt, the prevalence of ESRD in 2008 was 483 per million population [2] and this prevalence is presumed to be increasing [3].

It is well established that ESRD is a state of chronic systemic inflammation [4], which is attributed to both dialysis-related and dialysis-unrelated factors [5]. ESRD patients have high cytokine's concentrations due to both increased production and decreased renal clearance [6].

The difference between individuals in the progression to ESRD may be due to differences in the genetic susceptibility [7]. Moreover, the prevalence of inflammation in patients with chronic kidney disease (CKD) varies significantly between ethnic groups, suggesting that genetic factors may be a major contributory factor for the development of systemic inflammation [8].

Epigenetics refer to heritable changes of gene expression and gene function without changing the DNA sequence [9]. DNA methylation is a major epigenetic modification of the genome that has attracted a lot of interest due to the relative ease by which it can be studied, and having the potential to silence gene expression [10]. Differences in DNA methylation were associated with predisposition and/or treatment in ESRD patients [11].

It is of interest that inflammation may also promote aberrant DNA methylation, where inflammatory cytokine might exert an impact on epigenetic changes in cells via regulation of a DNA methyltransferase gene [12]. Additionally, aberrant DNA hypermethylation was associated with inflammation and poor outcome in CKD stage five patients [13].

Interferon gamma (IFN- $\gamma$ ) is a typical pro-inflammatory cytokine
[14] involved in several inflammatory diseases such as gangrenous appendicitis [15], inflammatory bowel disease [16], rheumatoid arthritis [17] and ESRD [18].

The gene coded for human IFN- $\gamma$ is mapped on chromosome $12 \mathrm{q} 14$ [19]. Increased IFN- $\gamma$ gene transcription has been correlated with hypomethylation of the promoter region in various inflammatory diseases as inflammatory bowel disease [20], periodontitis and gingivitis [21].

The suppressor of cytokine signaling (SOCS) family consists of eight proteins: cytokine-inducible $\mathrm{SH}_{2}$ protein (CIS) and SOCS1-SOCS7. Their expressions are induced by various cytokines or growth factors. They act via a negative feedback loop to inhibit the Janus kinase (JAK)/ signal transducers and activators of the transcription (STAT) mediated cytokine signaling initiated by that cytokine or by other cytokines [22].

Among eight SOCS proteins, the most potent ones are SOCS1 and SOCS3 [23]. SOCS1 acts by binding directly to JAK proteins, while SOCS3 inhibits signaling by binding to phosphorylated tyrosine sites on the cytoplasmic domain of the activated cytokine receptor [24]. The human SOCS1 gene is located on chromosome 16p13.1 [25], whereas human SOCS3 gene is mapped to chromosome 17q25.3 [26].

*Corresponding author: Dina Abo-Elmatty, Department of Biochemistry, Faculty of Pharmacy, Suez Canal University, Ismailia, Egypt, Fax: +20 643230741; E-mail: dinawahadan@yahoo.com.

Received July 24, 2013; Accepted October 23, 2013; Published October 26, 2013

Citation: Ghattas M, El-shaarawy F, Mesbah N, Abo-Elmatty D (2013) The Methylation Profile of IFN- $\gamma$, SOCS1 and SOCS3 Promoter Regions in End-Stage Renal Disease. J Data Mining Genomics Proteomics 4: 144. doi:10.4172/21530602.1000144

Copyright: (c) 2013 Ghattas M, et al. This is an open-access article distributed under the terms of the Creative Commons Attribution License, which permits unrestricted use, distribution, and reproduction in any medium, provided the original author and source are credited. 
Citation: Ghattas M, El-shaarawy F, Mesbah N, Abo-Elmatty D (2013) The Methylation Profile of IFN- $\gamma$, SOCS1 and SOCS3 Promoter Regions in End-Stage Renal Disease. J Data Mining Genomics Proteomics 4: 144. doi:10.4172/2153-0602.1000144

Page 2 of 7

Negative feedback regulation of the inflammatory pathways by SOCS was very important for the immune and inflammatory regulation [27]. Therefore, the loss of this regulation could have a vital role in disease progression. SOCS1 has been suggested in preventing inflammation by restricting the cytokine signals [28]. Moreover, dysregulation of SOCS3 is involved in inflammatory diseases in the gastrointestinal tract [29] and joints [30].

SOCS1 or SOCS3 hypermethylation can activate the JAK/STAT signaling pathway [31] and this signaling pathway has increasingly been implicated in the pathophysiology of renal disease [32] and in the development of renal interstitial fibrosis [33] and diabetic nephropathy [34].

The DNA methylation of IFN- $\gamma[20]$, SOCS1 [35] and SOCS3 [36] genes were previously studied in several inflammatory diseases. However, no epigenetic study was done regarding the relationship of DNA methylation in these genes with ESRD disease. Therefore, the aim of the present study is to explore the possible role of IFN- $\gamma$, SOCS1 and SOCS3 genes promoter methylation in the pathogenesis of ESRD.

\section{Materials and Methods}

\section{Subjects}

A total of 192 Egyptian individuals, including 96 cases of ESRD patients and 96 age, sex and ethnically matched healthy controls were enrolled in the present study. Patients were selected from the Department of Nephrology, a super specially center at El-Arish and Beer El-Abd in Nroth Sinai. The study was initiated in July 2012. The inclusion criterion in patient selection was constantly elevated serum creatinine level $>4.0 \mathrm{mg} / \mathrm{dL}$ or glomerular filtration rate (GFR) $<15$ $\mathrm{mL} / \mathrm{min} / 1.73 \mathrm{~m}^{2}$ estimated by Modification of Diet in Renal Disease (MDRD) formula [37]. All the patients selected for the present study were on regular hemodialysis for at least three months and dialyzed three times a week for 3-4 h. A full medical history was obtained from an interview of each subject at the time of enrollment into the study. The current study was approved by the Human Ethics Committee of the Faculty of Pharmacy Suez Canal University, and a written informed consent was obtained from each participant.

\section{Laboratory investigations}

Venous blood samples were collected after a 12 hours fast (for patients, the blood collected under predialysis conditions). The serum creatinine was estimated using the Jaffé reaction (VITRO SCIENT, EGYPT) while, the serum urea, total cholesterol, triglyceride and HDL-C were measured by the enzymatic colorimetric method (BIODIAGNOSTIC, EGYPT). Low-density lipoprotein-cholesterol (LDL-C) level was calculated using the Friedwald formula [38].

\section{Methylation analysis of IFN- $\gamma$, SOCS 1 and SOCS3 genes}

DNA was extracted from peripheral blood using Wizard Genomic DNA purification kit (PROMEGA Cat No.A1120) according to the manufacturer's instruction. Extracted DNA (two $\mu \mathrm{g}$ ) was bisulfite converted according to EpiTect ${ }^{\circledR}$ Bisulfite conversion kit (QIAGEN). MSP was carried out as initially described by Herman et al. [39] and modified DNA was subjected to two separate PCR reactions using either a methylated (M) or unmethylated primer (U) pair. PCR amplification for IFN- $\gamma$ [40], SOCS1 [41] and SOCS3 [42] promoter regions was performed under conditions as previously described. The sequences of the methylated and unmethylated primer pairs used and the PCR products size are listed in Table 1.

\begin{tabular}{|c|c|c|c|}
\hline Gene & Primer pair sequence & $\begin{array}{l}\text { Annealing } \\
\text { temperature } \\
\text { (cycle) }\end{array}$ & $\begin{array}{l}\text { Product } \\
\text { size }\end{array}$ \\
\hline \multirow[t]{4}{*}{ IFN- $\gamma$} & MF: 5'- AAGAGTTAATATTTTATTAGGGCGA-3' & $52^{\circ} \mathrm{C}(35)$ & $151 \mathrm{bp}$ \\
\hline & MR: 5'-TAAACTCCTTAAATCCTTTAACGAT-3' & & \\
\hline & UF: 5'-TGAAGAGTTAATATTITATTAGGGTGA -3' & $52^{\circ} \mathrm{C}(35)$ & $154 \mathrm{bp}$ \\
\hline & UR: 5'-TAAACTCCTTAAATCCTTTAACAAT -3' & & \\
\hline \multirow[t]{4}{*}{ socs1 } & MF: 5'-TTGTTCGGAGGTCGGATTT-3' & $65^{\circ} \mathrm{C}(35)$ & 218 bp \\
\hline & MR: 5'ACTAAAACGCTACGAAACCG-3' & & \\
\hline & $\begin{array}{l}\text { UF: 5'-TTTTTTGGTGTTGTTTGGAGGTTG- } \\
\text { GATTTT-3' }\end{array}$ & $60^{\circ} \mathrm{C}(35)$ & 243 bp \\
\hline & $\begin{array}{l}\text { UR:5'-AAAACAAAACAATAAACTAAAACACTA- } \\
\text { CAAAA CCA-3' }\end{array}$ & & \\
\hline \multirow[t]{4}{*}{ socs3 } & MF: 5'-GGAGATTTTAGGTTTTCGGAATATTTC -3' & $60^{\circ} \mathrm{C}(30)$ & 142 bp \\
\hline & MR: 5'- CCCCCGAAACTACCTAAACGCCG -3' & & \\
\hline & $\begin{array}{l}\text { UF: 5'-GTTGGAGATTTTAGGTTTTTG- } \\
\text { GAATATTTT-3' }\end{array}$ & $60^{\circ} \mathrm{C}(30)$ & $151 \mathrm{bp}$ \\
\hline & UR: 5'-AAACCCCCAAAACTACCTAAACACCA -3' & & \\
\hline
\end{tabular}

M: Methylated; U: Unmethylated; F: Forward; R: Reverse.

Table 1: Primer sequences for MSP analysis of IFN- $\mathrm{Y}$, SOCS1 and SOCS3 promoter regions.

PCR reactions were performed in a final volume of $25 \mu \mathrm{l}$ containing $2 \mu \mathrm{l}$ ofbisulfite treated DNA, $200 \mathrm{nmol} / \mathrm{leach}$ of forward and reverse primer, $200 \mu \mathrm{M}$ of each dNTPs, $1 \mathrm{X}$ PCR buffer, $1.5 \mathrm{mM} \mathrm{MgCl}_{2}$ and $1.25 \mathrm{U}$ of HotStarTaq DNA Polymerase (QIAGEN). The amplification products were separated on $2.5 \%$ agarose gel, stained with ethidium bromide. We used completely methylated and unmethylated human genomic DNA (EPITECT ${ }^{\circledR}$ PCR CONTROL DNA, QIAGEN) as positive and negative controls for the methylated gene respectively.

\section{Statistical analysis}

The chi-square test was used to compare categorical variables such as gender, while the fisher's exact test was used to investigate the differences in the methylation status of the studied genes between ESRD and control groups. The Mann-Whitney test was used to determine the differences in clinical and biochemical characteristics between patients and controls. The correlation of IFN- $\gamma$ and SOCS1 promoter methylation with different parameters in ESRD patients was estimated using the Kruskal-Wallis test. P-values of less than 0.05 were considered statistically significant. All statistical tests were done using SPSS version 16.0. All data were presented as a median (range).

\section{Results}

\section{Clinical and biochemical characteristics of ESRD patients and controls}

We screened 96 ESRD patients and 96 controls with a median age of 50 and 46 years, respectively (range: $30-70$ years)] for IFN- $\gamma$, SOCS1 and SOCS3 promoter methylation. The clinical and biochemical characteristics of ESRD patients and controls are summarized in Table 2. The male to the female ratio for each group was $(59.38: 40.62 \%$ in patients, as compared to $62.5: 37.5 \%$ in controls). Both groups were age and sex matched. The ESRD patients maintained on hemodialysis with a median duration of 35.5 months (range: 7:108 months). The median (range) value of estimated glomerular filtration rate (eGFR) in patients was $7.007 \mathrm{ml} / \mathrm{min} / 1.73 \mathrm{~m}^{2}(2.86-14.09)$ which was significantly lower than the control group $(\mathrm{p}<0.001)$.

The two most important renal functional parameters, i.e., serum creatinine and serum urea levels were significantly increased among the patients as compared with the controls. Patients had significant higher 
Citation: Ghattas M, El-shaarawy F, Mesbah N, Abo-Elmatty D (2013) The Methylation Profile of IFN- $\gamma$, SOCS1 and SOCS3 Promoter Regions in End-Stage Renal Disease. J Data Mining Genomics Proteomics 4: 144. doi:10.4172/2153-0602.1000144

Page 3 of 7

\begin{tabular}{|c|c|c|c|}
\hline Variables & $\begin{array}{l}\text { Control } \\
(n=96)\end{array}$ & $\begin{array}{l}\text { ESRD } \\
(n=96)\end{array}$ & $\mathbf{P}$ \\
\hline Age (Years) & $\begin{array}{l}46 \\
(30-70)\end{array}$ & $\begin{array}{l}50 \\
(30-70)\end{array}$ & $0.4^{\mathrm{a}}$ \\
\hline $\operatorname{Sex}(M / F), n(\%)$ & $\begin{array}{l}60 / 36 \\
(62.5 / 37.5 \%)\end{array}$ & $\begin{array}{l}57 / 39 \\
(59.38 / 40.62 \%)\end{array}$ & $0.657^{\mathrm{b}}$ \\
\hline $\begin{array}{l}\text { Hemodialysis } \\
\text { Duration (Months) }\end{array}$ & NA & \begin{tabular}{|l|}
35.50 \\
$(7-108)$
\end{tabular} & - \\
\hline $\begin{array}{l}\text { eGFR } \\
\left(\mathrm{ml} / \mathrm{min} / 1.73 \mathrm{~m}^{2}\right)\end{array}$ & $\begin{array}{l}99.8 \\
(90.01-129.04)\end{array}$ & $\begin{array}{l}7.007 \\
(2.86-14.09)\end{array}$ & $<0.001^{a}$ \\
\hline Creatinine (mg/dl) & $0.8(0.6-1)$ & $\begin{array}{l}7.69 \\
(4.2-14.5)\end{array}$ & $<0.001^{a *}$ \\
\hline Urea $(\mathrm{mg} / \mathrm{dl})$ & $\begin{array}{l}22.80 \\
(15.4-39.22)\end{array}$ & $\begin{array}{l}104.77 \\
(51.14-186.9)\end{array}$ & $<0.001^{a *}$ \\
\hline Total Cholesterol (mg/dl) & $\begin{array}{l}167.2838 \\
(117.0-210)\end{array}$ & $\begin{array}{l}154.83 \\
(103.23-332)\end{array}$ & $0.150^{\mathrm{a}}$ \\
\hline Triglyceride (mg/dl) & $\begin{array}{l}125.50 \\
(62.86-152)\end{array}$ & $\begin{array}{l}151.76 \\
(91.06-366.6)\end{array}$ & $<0.001^{a *}$ \\
\hline HDL-C (mg/dl) & $\begin{array}{l}41.17 \\
(27.94-62)\end{array}$ & $\begin{array}{l}32.58 \\
(20.59-60.20)\end{array}$ & $<0.001^{a *}$ \\
\hline VLDL-C (mg/dl) & $\begin{array}{l}25.10 \\
(12.57-30.40)\end{array}$ & $\begin{array}{l}30.3532 \\
(18.21-73.33)\end{array}$ & $<0.001^{a *}$ \\
\hline LDL-C (mg/dl) & $\begin{array}{l}105.006 \\
(33.8-152.2)\end{array}$ & \begin{tabular}{|l|}
84.21 \\
$(21.26-255.1)$
\end{tabular} & $0.087^{a}$ \\
\hline Systolic BP (mm Hg) & $\begin{array}{l}120 \\
(90-135)\end{array}$ & $\begin{array}{l}150 \\
(110-190)\end{array}$ & $<0.001^{a *}$ \\
\hline Diastolic BP (mm Hg) & $\begin{array}{l}70 \\
(55-85)\end{array}$ & $\begin{array}{l}90 \\
(65-100)\end{array}$ & $<0.001^{a *}$ \\
\hline
\end{tabular}

Data are presented as median (range).

aMann-Whitney test.

${ }^{\mathrm{b}}$ Chi-square test.

*Statistically significant compared with control at $\mathrm{P}<0.05$

eGFR estimated glomerular filtration rate.

NA Not applicable.

Table 2: Clinical and biochemical characteristics of ESRD patients and controls.

\begin{tabular}{|c|c|c|c|c|c|c|}
\hline \multirow[t]{2}{*}{ Gene } & & \multicolumn{3}{|c|}{ Methylation status } & \multirow[t]{2}{*}{ Total } & \multirow[t]{2}{*}{$\mathbf{P}$} \\
\hline & & $\mathbf{U}$ & $\mathrm{U} / \mathrm{M}$ & $\mathbf{M}$ & & \\
\hline \multirow[t]{2}{*}{ IFN- $\gamma$} & Control n (\%) & $\begin{array}{c}0 \\
(0 \%)\end{array}$ & $\begin{array}{c}61 \\
(63.54 \%)\end{array}$ & $\begin{array}{c}35 \\
(36.46 \%)\end{array}$ & 96 & \multirow[t]{2}{*}{$0.02^{*}$} \\
\hline & ESRD n (\%) & $\begin{array}{c}7 \\
(7.3 \%)\end{array}$ & $\begin{array}{c}59 \\
(61.5 \%)\end{array}$ & $\begin{array}{c}30 \\
(31.2 \%)\end{array}$ & 96 & \\
\hline \multirow[t]{2}{*}{ SOCS1 } & Control n (\%) & $\begin{array}{c}96 \\
(100 \%)\end{array}$ & $\begin{array}{c}0 \\
(0 \%)\end{array}$ & $\begin{array}{c}0 \\
(0 \%)\end{array}$ & 96 & \multirow[t]{2}{*}{$0.014^{*}$} \\
\hline & ESRD n (\%) & $\begin{array}{c}89 \\
(92.7 \%)\end{array}$ & $\begin{array}{c}5 \\
(5.2 \%)\end{array}$ & $\begin{array}{c}2 \\
(2.1 \%)\end{array}$ & 96 & \\
\hline \multirow[t]{2}{*}{ SOCS3 } & Control n (\%) & $\begin{array}{c}96 \\
(100 \%)\end{array}$ & $\begin{array}{c}0 \\
(0 \%)\end{array}$ & $\begin{array}{c}0 \\
(0 \%)\end{array}$ & 96 & \\
\hline & ESRD n (\%) & $\begin{array}{c}96 \\
(100 \%)\end{array}$ & $\begin{array}{c}0 \\
(0 \%)\end{array}$ & $\begin{array}{c}0 \\
(0 \%)\end{array}$ & 96 & \\
\hline
\end{tabular}

$\cup$ Total unmethylation (only the unmethylated allele)

U/M Partial methylation (both unmethylated and methylated alleles)

$\mathrm{M}$ Total methylation (only the methylated allele)

The P-value represents Fisher's exact test results of ESRD patients compared with control group.

*Statistically significant at $\mathrm{P}<0.05$.

Table 3: IFN- $\gamma$, SOCS1 and SOCS3 promoter methylation in peripheral blood of ESRD patients and controls.

levels of serum triglyceride and VLDL-C than controls. However, serum HDL-C level was significantly lower in the patient group comparing to the normal subjects. On the other hand, no significant differences in total cholesterol and LDL-C levels were detected between the two groups ( $\mathrm{p}=0.15$ and 0.087 , respectively). Furthermore, there was a significant increase in both of systolic and diastolic blood pressure in the patients in comparison to the controls $(\mathrm{p}<0.001)$.

\section{Methylation status of IFN- $\gamma$, SOCS1 and SOCS3 promoter regions}

The methylation-specific polymerase chain reaction (MSP) results of the studied genes promoters are shown in Table 3. The majority of the samples in controls (100\%) and ESRD (92.7\%) patients showed a positive methylation for IFN- $\gamma$ promoter region. In the control group, $36.46 \%(n=35)$ of the samples showed total methylation (positive only for the methylated sequence of the gene), and $63.54 \%(n=61)$ showed partial methylation (positive for both methylated and unmethylated sequences). Unmethylated samples (amplification only with the unmethylated primers) were observed only in the patient group. In the ESRD group, $31.2 \%(n=30)$ of the samples were totally methylated, $61.5 \%(n=59)$ of the samples were partially methylated and $7.3 \%$ $(n=7)$ were totally unmenthylated. The difference between groups was statistically significant $(\mathrm{P}=0.02)$.

As regards SOCS1, its promoter methylation was detected in seven of 96 ESRD patients (total methylation $2.1 \%[n=2]$ and partial methylation $5.2 \%[n=5])$, but it was not present in any of the control samples. While total unmethylation was detected in $92.7 \%(\mathrm{n}=89)$ of ESRD patients and $100 \%$ of controls. The difference between groups was statistically significant $(\mathrm{P}=0.014)$. However, neither $\mathrm{ESRD}$ patients nor controls demonstrated any aberrant methylation within the SOCS3 promoter region (Figure 1).

\section{Correlation of IFN- $\gamma$ and SOCS1 promoter methylation with clinical and biochemical characteristics in ESRD patients}

As summarized in Table 4, we compared several clinical and biochemical characteristics with methylation status within the IFN- $\gamma$ and SOCS1 promoter regions in ESRD patients. For IFN- $\gamma$, compared with totally and partially methylated, totally unmetylated group showed a significantly lower eGFR, higher serum creatinineand serum total cholesterol levels $(\mathrm{P}=0.018,0.012$ and 0.041 , respectively), while the other parameters did not significantly differ between the groups. However, the methylation of the SOCS1 promoter region had no apparent associations with any of the studied parameters in ESRD patients.

\section{Discussion}

Inflammation is common in CKD and worsens as the disease progresses towards ESRD [6], where the overproduced proinflammatory cytokines may play a significant role in renal injury [43]. DNA methylation is an important epigenetic modification that can play a critical regulatory role in both normal and pathological cellular processes [44]. DNA methylation, particularly in the promoter region of genes, is involved in down regulation of gene expression [45]. The differences in DNA methylation were associated with susceptibilityto ESRD [11]. The current study aimed to determine the methylation status of the IFN- $\gamma$, SOCS1 and SOCS3 promoter regions using DNA isolated from peripheral blood of ESRD patients and controls and the correlation of this methylation with the clinical and biochemical characteristics of these patients.

Our data demonstrated that both the ESRD and the control groups showed a high frequency of total and partial methylation of IFN- $\gamma$ promoter region. This indicates that the methylation of IFN- $\gamma$ gene is a frequent event in the peripheral blood $[20,40]$. However, total unmethylation was observed only in the ESRD group (7.3\%), and statistical difference was observed among groups $(\mathrm{P}=0.02)$. Previous study linked hypomethylated profile within IFN- $\gamma$ promoter with other chronic inflammatory disease as chronic periodontitis [21]. 
Citation: Ghattas M, El-shaarawy F, Mesbah N, Abo-Elmatty D (2013) The Methylation Profile of IFN- $\gamma$, SOCS1 and SOCS3 Promoter Regions in End-Stage Renal Disease. J Data Mining Genomics Proteomics 4: 144. doi:10.4172/2153-0602.1000144

(a) IFN-T

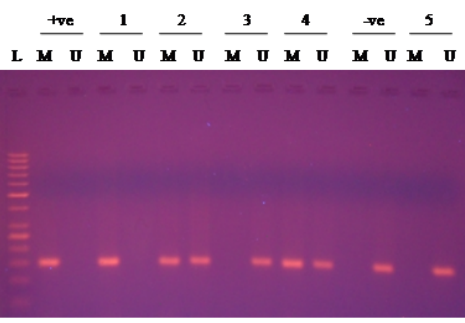

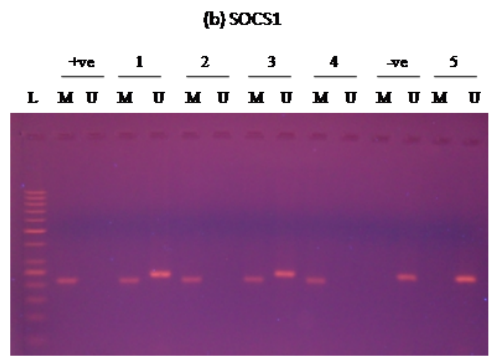

(c) $\operatorname{socs3}$

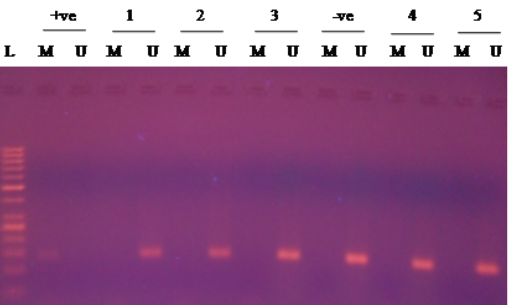

Figure 1: Representative data showing the methylation status of IFN- $\gamma$, SOCS1 and SOCS3 genes promoter. U unmethylated DNA, M methylated DNA, L 50 bp DNA ladder, +ve: positive control (universal methylated DNA), -ve: negative control (universal unmethylated DNA). (a) IFN- $\gamma$ promoter was totally methylated in samples 1 , partially methylated in samples 2 and 4 but totally unmethylated in sample3 and 5 . Methylated PCR products are shown as a 151-bp band in Lane M, whereas unmethylated PCR products are shown as a 154-bp band in Lane U (b) SOCS1 promoter was totally methylated in samples 2 and 4, partially methylated in samples 1 and 3 but totally unmethylated in sample 5 . Methylated PCR products are shown as a 218 bp band in Lane M, whereas unmethylated PCR products are shown as a $243 \mathrm{bp}$ band in Lane U (c) SOCS3 promoter was fully unmethylated in all samples. Methylated PCR products are shown as a 142 bp band in Lane M, whereas unmethylated PCR products are shown as a 151 bp band in Lane U.

\begin{tabular}{|c|c|c|c|c|c|c|c|c|}
\hline \multirow[b]{2}{*}{ Variables } & \multicolumn{3}{|c|}{ IFN- $\gamma$ methylation status } & \multicolumn{5}{|c|}{ socs1 methylation status } \\
\hline & $U(n=7)$ & $U / M(n=59)$ & $M(n=30)$ & $P$ & $U(n=89)$ & $U / M(n=5)$ & $M(n=2)$ & $P$ \\
\hline $\begin{array}{l}\text { Age } \\
\text { (Years) }\end{array}$ & $\begin{array}{c}40 \\
(30-61)\end{array}$ & $\begin{array}{c}48 \\
(30-70)\end{array}$ & $\begin{array}{c}50.5 \\
(30-70)\end{array}$ & $0.49^{a}$ & $\begin{array}{c}50 \\
(30-70)\end{array}$ & $\begin{array}{c}44 \\
(30-65)\end{array}$ & $\begin{array}{c}47.5 \\
(35-60)\end{array}$ & $0.957^{a}$ \\
\hline $\begin{array}{l}\text { Sex } \\
(M / F), n \%\end{array}$ & $\begin{array}{c}3 / 4 \\
(42.9 / 5.1 \%)\end{array}$ & $\begin{array}{c}35 / 24 \\
(59.3 / 40.7 \%)\end{array}$ & $\begin{array}{c}19 / 11 \\
(63.3 / 36.7 \%)\end{array}$ & $0.61^{\mathrm{b}}$ & $\begin{array}{c}54 / 35 \\
(60.7 / 39.3 \%)\end{array}$ & $\begin{array}{c}3 / 2 \\
(60 / 40 \%)\end{array}$ & $\begin{array}{c}0 / 2 \\
(0 / 100 \%)\end{array}$ & $0.225^{\mathrm{b}}$ \\
\hline $\begin{array}{l}\text { Creatinine } \\
(\mathrm{mg} / \mathrm{dl})\end{array}$ & $\begin{array}{c}9.1 \\
(5.2-11.6)\end{array}$ & $\begin{array}{c}8.57 \\
(5-14.5)\end{array}$ & $\begin{array}{c}6.3 \\
(4.2-14.33)\end{array}$ & $0.012^{\mathrm{a} *}$ & $\begin{array}{c}7.66 \\
(4.2-14.5)\end{array}$ & $9(5.2-11)$ & $9.3(7-11.6)$ & $0.733^{a}$ \\
\hline $\begin{array}{l}\text { eGFR } \\
\left(\mathrm{ml} / \mathrm{min} / 1.73 \mathrm{~m}^{2}\right)\end{array}$ & $\begin{array}{c}6.36 \\
(3.96-9.79)\end{array}$ & $\begin{array}{c}6.68 \\
(2.86-13.91)\end{array}$ & $\begin{array}{c}8.12 \\
(3.46-14.09)\end{array}$ & $0.018^{\mathrm{a} *}$ & $\begin{array}{c}7.03 \\
(2.86-14.09)\end{array}$ & $\begin{array}{c}7.29 \\
(5.04-9.74)\end{array}$ & $\begin{array}{c}5.16 \\
(3.96-3.36)\end{array}$ & $0.366^{\mathrm{a}}$ \\
\hline $\begin{array}{l}\text { Hemodialysis } \\
\text { Duration (Months) }\end{array}$ & $\begin{array}{c}24 \\
(12-48)\end{array}$ & $\begin{array}{c}36 \\
(7-108)\end{array}$ & $\begin{array}{c}24 \\
(7-108)\end{array}$ & $0.62^{\mathrm{a}}$ & $\begin{array}{c}36 \\
(7-108)\end{array}$ & $24(12-36)$ & $\begin{array}{c}30 \\
(24-36)\end{array}$ & $0.431^{\mathrm{a}}$ \\
\hline $\begin{array}{l}\text { Urea } \\
\text { (mg/dl) }\end{array}$ & $\begin{array}{c}105 \\
(62-144.32)\end{array}$ & $\begin{array}{c}104.54 \\
(54.5-186.9)\end{array}$ & $\begin{array}{c}109.76 \\
(51.1-184.5)\end{array}$ & $0.89^{a}$ & $\begin{array}{c}105 \\
(51.1-186.9)\end{array}$ & $\begin{array}{c}95.45 \\
(89.7-120.4)\end{array}$ & $\begin{array}{c}99.77 \\
(79.5-120)\end{array}$ & $0.947^{\mathrm{a}}$ \\
\hline $\begin{array}{l}\text { Total } \\
\text { Cholesterol (mg/dl) }\end{array}$ & $\begin{array}{c}225.80 \\
(122.5-264.5)\end{array}$ & $\begin{array}{c}161.29 \\
(103.2-332)\end{array}$ & $\begin{array}{c}148.4 \\
(103.23-310)\end{array}$ & $0.041^{\mathrm{a} *}$ & $\begin{array}{c}154.83 \\
(103.23-332)\end{array}$ & $\begin{array}{c}220 \\
(141.9-258.06)\end{array}$ & $\begin{array}{c}174.19 \\
(122.6-225.8)\end{array}$ & $0.165^{a}$ \\
\hline $\begin{array}{l}\text { Triglyceride } \\
\text { (mg/dl) }\end{array}$ & $\begin{array}{c}166.66 \\
(136.6-266.7)\end{array}$ & $\begin{array}{c}166.66 \\
(91.1-366.7)\end{array}$ & $\begin{array}{c}145.32(106.2- \\
244.4)\end{array}$ & $0.20^{\mathrm{a}}$ & $\begin{array}{c}151.76 \\
(91.1-327.8)\end{array}$ & $\begin{array}{c}177.14 \\
(151.7-366.67)\end{array}$ & $\begin{array}{c}201.62 \\
(136.6-266.7)\end{array}$ & $0.268^{a}$ \\
\hline $\begin{array}{l}\text { HDL-C } \\
\text { (mg/dl) }\end{array}$ & $\begin{array}{c}35.29 \\
(30.88-39)\end{array}$ & $\begin{array}{c}32.81 \\
(20.59-60.2)\end{array}$ & $\begin{array}{c}30.88 \\
(21.88-47.06)\end{array}$ & $0.28^{\mathrm{a}}$ & $\begin{array}{c}32.35 \\
(20.59-60.2)\end{array}$ & $\begin{array}{c}32.35 \\
(31-39.71)\end{array}$ & $\begin{array}{c}35.14 \\
(35-35.29)\end{array}$ & $0.790^{\mathrm{a}}$ \\
\hline $\begin{array}{l}\text { VLDL-C } \\
(\mathrm{mg} / \mathrm{dl})\end{array}$ & $\begin{array}{c}33.33 \\
(27.32-53.33)\end{array}$ & $\begin{array}{c}33.33 \\
(18.21-73.3)\end{array}$ & $\begin{array}{c}29.06 \\
(21.25-48.9)\end{array}$ & $0.204^{\mathrm{a}}$ & $\begin{array}{c}30.35 \\
(18.2-65.56)\end{array}$ & $\begin{array}{c}35.42 \\
(30.35-73.3)\end{array}$ & $\begin{array}{c}40.32 \\
(27.32-53.33)\end{array}$ & $0.268^{a}$ \\
\hline $\begin{array}{l}\text { LDL-C } \\
\text { (mg/dl) }\end{array}$ & $149.11(60.26-200.3)$ & $\begin{array}{c}92.13 \\
(21.3-255.1)\end{array}$ & $\begin{array}{c}80.58 \\
(41.8-236.3)\end{array}$ & $0.103^{\mathrm{a}}$ & $\begin{array}{c}83.48 \\
(21.3-255.1)\end{array}$ & $\begin{array}{c}152.37 \\
(74.8-190.56)\end{array}$ & $\begin{array}{c}98.72 \\
(60.3-137.2)\end{array}$ & $0.237^{\mathrm{a}}$ \\
\hline $\begin{array}{l}\text { Systolic BP } \\
(\mathrm{mm} \mathrm{Hg})\end{array}$ & $\begin{array}{c}180 \\
(120-180)\end{array}$ & $\begin{array}{c}150 \\
(110-185)\end{array}$ & $\begin{array}{c}140 \\
(110-190)\end{array}$ & $0.26^{\mathrm{a}}$ & $\begin{array}{c}150 \\
(110-190)\end{array}$ & $\begin{array}{c}130 \\
(120-180)\end{array}$ & $\begin{array}{c}150 \\
(120-180)\end{array}$ & $0.644^{\mathrm{a}}$ \\
\hline $\begin{array}{l}\text { Diastolic BP } \\
(\mathrm{mm} \mathrm{Hg})\end{array}$ & $\begin{array}{c}95 \\
(70-100)\end{array}$ & $\begin{array}{c}90 \\
(65-100)\end{array}$ & $\begin{array}{c}90 \\
(70-100)\end{array}$ & $0.14^{\mathrm{a}}$ & $\begin{array}{c}90 \\
(65-100)\end{array}$ & $\begin{array}{c}80 \\
(70-100)\end{array}$ & $\begin{array}{c}92.5 \\
(85-100)\end{array}$ & $0.453^{a}$ \\
\hline
\end{tabular}

Data are presented as median (range).

$\cup$ Total unmethylation (only the unmethylated allele)

U/M Partial methylation (both unmethylated and methylated alleles)

$\mathrm{M}$ Total methylation (only the methylated allele)

aKruskal-Wallis test.

${ }^{\mathrm{b}} \mathrm{Chi}$-square test.

*Statistically significant compared at $\mathrm{P}<0.05$.

eGFR estimated glomerular filtration rate.

Table 4: Correlation of IFN- $\gamma$ and SOCS1 promoter methylation with clinical and biochemical characteristics in ESRD patients. 
The current study investigated the correlation of several clinical and biochemical characteristics with the IFN- $\gamma$ promoter methylation in ESRD patients. From all studied parameters, only the eGFR, serum creatinine and serum total cholesterol levels, were significantly different between the totally methylated, partially methylated and totally unmethylated groups. The patients with the totally unmetylated IFN- $\gamma$ promoter region had significantly lower eGFR and significantly higher serum creatinine than the totally and the partially methylated groups. This finding could be attributed to IFN- $\gamma$ role as a macrophage activating cytokine, where macrophages are responsible for renal injury and glomerulonephritis [46]. Additionally, Marko et al. [47] found that IFN $-\gamma$ receptor deficiency reduced inflammation and tubulointerstitial damage and improved glomerular filtration rate in IFN- $\gamma$ receptor knockout mice.

Moreover, our results indicated that total unmethylation of IFN- $\gamma$ promoter region was associated with a significant increase in serum total cholesterol level. During hypercholesterolemia, IFN- $\gamma$ causes the generation of superoxide from vascular $\mathrm{NAD}(\mathrm{P}) \mathrm{H}$ oxidase, which leads to an impairment of endothelium-dependent vasodilation [48]. On the other hand, in our population LDL-C level did not significantly differ between patients with the methylated and the unmethylated IFN- $\gamma$ promoter region. In general, elevated LDL-C level is unusual in ESRD patients [49] because hypertriglyceridemia leads to the shift of LDL particle size toward a small, dense apo-B-rich LDL, which is more atherogenic [50].

The current study showed aberrant promoter methylation of SOCS1 gene (partial and total methylation were $5.2 \%$ and $2.1 \%$, respectively) in the peripheral blood of ESRD patients. However, no methylation was detected in controls. This difference was statistically significant $(\mathrm{P}=0.014)$. The result from our study is considered reliable because it was consistent with Johan et al. [51] who discovered that $11 \%$ of the SOCS1 promoter region was methylated in the peripheral blood of myelodysplastic syndrome, and no methylation was detected in the healthy controls using the same primer sequences.

Previous study proved that methylation of SOCS1 promoter region inactivated translation and diminished expression of SOCS1 mRNA in hepatocellular carcinoma [52]. SOCS1 downregulation leading to JAK/ STAT signaling pathway activation with a subsequent development of renal interstitial fibrosis [33] and diabetic nephropathy [34].

Furthermore, the current study did not find a correlation between SOCS1 methylation and any of the biochemical or clinical parameters in ESRD patients. This may be due to the presence of a small number of patients in the fully or partially methylated groups ( 2 and 5 patients, respectively).

The present results concerning IFN- $\gamma$ and SOCS1 promoter methylation emphasized SOCS1 role in negative regulation of IFN- $\gamma$ signaling. Where the previous study in experimental animal found that SOCS1 deficiency leads to over responsiveness to IFN- $\gamma$, while SOCS1 over expression leads to IFN- $\gamma$ reduced response [53].

Regarding SOCS3 promoter methylation, no methylation was detected in our patients or the control group. In contrary to our finding, previous study using the same primer sequence discovered aberrant methylation in primary malignant melanomas and melanocytic nevi cell lines [42]. The explanation of these conflicting results may be because our study assessed DNA metyhlation in peripheral blood samples and not in tissues, and SOCS3 promoter methylation may be tissuespecific rather than disease-specific. In support of this explanation, Barrio et al. [54] didn't discover any aberrant methylation at SOCS3 gene in peripheral blood of patients with polycythemia vera, essential thrombocythemia or in healthy controls. Additionally Rastmanesh et al. [55] did not find any significant difference of SOCS3 expression in monocytes and lymphocytes of ESRD patients versus controls.

The current methylation status differences between SOCS1 and SOCS3 in our study indicated that SOCS3 has a less effective role in negative regulation of cytokine signaling in ESRD. This could be explained by the difference in timing response of SOCSs expression to the stimulating cytokine. SOCS3 synthesis was maximal at four hours and then decreased to baseline, whereas SOCS1 was expressed later and remained increased even after 24 hours. Therefore, SOCS3 first modulates the inflammatory response, while SOCS1 regulates the activated pathways after longer exposition to the inflammatory stimuli [56]. Further studies regarding SOCS expression may be required to fully resolve the relevance of SOCS methylation.

In Conclusions the methylation profile of IFN- $\gamma$ and SOCS1 promoter regions in DNA isolated from peripheral blood plays an important role in the pathogenesis of ESRD. However, SOCS3 methylation at the promoter region is not a key event in the pathogenesis of this disease. Therefore, the current study highlighted the role of epigenetic modification in disease progression. Our results should be completed with gene expression studies, in order to confirm its significance in the pathogenesis of ESRD. However, taking in consideration that there is a complex interplay of other factors affecting genes expression in ESRDsuch as polymorphism [57], uremia [58] and proteinuria [59].

\section{References}

1. Mittal RD, Manchanda PK (2007) Is low-frequency distribution of TGF-beta genotype associated with increased risk for end-stage renal disease? DNA Cell Biol 26: 172-177.

2. Mahmoud KM, Sheashaa HA, Gheith OA, Wafa EW, Agroudy AE, et al. (2010) Continuous ambulatory peritoneal dialysis in Egypt: progression despite handicaps. Perit Dial Int 30: 269-273.

3. Soliman AR, Fathy A, Roshd D (2012) The growing burden of end-stage renal disease in Egypt. Ren Fail 34: 425-428.

4. Yao Q, Lindholm B, Stenvinkel $P(2004)$ Inflammation as a cause of malnutrition atherosclerotic cardiovascular disease, and poor outcome in hemodialysis patients. Hemodial Int 8: 118-129.

5. Cheung WW, Paik KH, Mak RH (2010) Inflammation and cachexia in chronic kidney disease. Pediatr Nephrol 25: 711-724.

6. Kalantar-Zadeh K, Stenvinkel P, Pillon L, Kopple JD (2003) Inflammation and nutrition in renal insufficiency. Adv Ren Replace Ther 10: 155-169.

7. Köttgen A, Pattaro C, Böger CA, Fuchsberger C, Olden M, et al. (2010) New loci associated with kidney function and chronic kidney disease. Nat Genet 42 : 376-384

8. Rao M, Wong C, Kanetsky P, Girndt M, Stenvinkel P, et al. (2007) Cytokine gene polymorphism and progression of renal and cardiovascular diseases. Kidney Int 72: 549-556.

9. Stenvinkel P, Ekström TJ (2008) Epigenetics and the uremic phenotype: a matter of balance. Contrib Nephrol 161: 55-62.

10. Barres R, Zierath JR (2011) DNA methylation in metabolic disorders. Am J Clin Nutr 93: 897S-900.

11. Sapienza C, Lee J, Powell J, Erinle O, Yafai F, et al. (2011) DNA methylation profiling identifies epigenetic differences between diabetes patients with ESRD and diabetes patients without nephropathy. Epigenetics 6: 20-28.

12. Hodge DR, Xiao W, Clausen PA, Heidecker G, Szyf M, et al. (2001) Interleukin-6 regulation of the human DNA methyltransferase (HDNMT) gene in human erythroleukemia cells. J Biol Chem 276: 39508-39511.

13. Stenvinkel P, Karimi M, Johansson S, Axelsson J, Suliman M, et al. (2007) Impact of inflammation on epigenetic DNA methylation - a novel risk factor for 
Citation: Ghattas M, El-shaarawy F, Mesbah N, Abo-Elmatty D (2013) The Methylation Profile of IFN- $\gamma$, SOCS1 and SOCS3 Promoter Regions in End-Stage Renal Disease. J Data Mining Genomics Proteomics 4: 144. doi:10.4172/2153-0602.1000144

cardiovascular disease? J Intern Med 261: 488-499.

14. Viana MB, Cardoso FP, Diniz MG, Costa FO, da Costa JE, et al. (2011) Methylation pattern of $\mathrm{IFN}-\hat{l}^{3}$ and $\mathrm{IL}-10$ genes in periodontal tissues. Immunobiology 216: 936-941.

15. Hachim MY, Ahmed AH (2006) The role of the cytokines and cell-adhesion molecules on the immunopathology of acute appendicitis. Saudi Med J 27: 1815-1821.

16. Ito R, Shin-Ya M, Kishida T, Urano A, Takada R, et al. (2006) Interferon-gamma is causatively involved in experimental inflammatory bowel disease in mice. Clin Exp Immunol 146: 330-338.

17. Skurkovich B, Skurkovich S (2003) Anti-interferon-gamma antibodies in the treatment of autoimmune diseases. Curr Opin Mol Ther 5: 52-57.

18. Yousefi S, Vaziri ND, Carandang G, Cesario T (1987) Evaluation of the in vitro production of interferon gamma and other lymphokines in uremic patients. Proc Soc Exp Biol Med 184: 179-185

19. Kantarci OH, Hebrink DD, Schaefer-Klein J, Sun Y, Achenbach S, et al. (2008) Interferon gamma allelic variants: sex-biased multiple sclerosis susceptibility and gene expression. Arch Neurol 65: 349-357.

20. Gonsky R, Deem RL, Targan SR (2009) Distinct Methylation of IFNG in the Gut. $\mathrm{J}$ Interferon Cytokine Res 29: 407-414.

21. Zhang S, Crivello A, Offenbacher S, Moretti A, Paquette DW, et al. (2010) Interferon-gamma promoter hypomethylation and increased expression in chronic periodontitis. J Clin Periodontol 37: 953-961.

22. Tan JC, Rabkin R (2005) Suppressors of cytokine signaling in health and disease. Pediatr Nephrol 20: 567-575

23. Nicholson SE, Willson TA, Farley A, Starr R, Zhang JG, et al. (1999) Mutationa analyses of the SOCS proteins suggest a dual domain requirement but distinct mechanisms for inhibition of LIF and IL-6 signal transduction. EMBO J 18: $375-$ 385

24. Inagaki-Ohara K, Hanada T, Yoshimura A (2003) Negative regulation of cytokine signaling and inflammatory diseases. Curr Opin Pharmacol 3: 435-442.

25. Yandava CN, Pillari A, Drazen JM (1999) Radiation hybrid and cytogenetic mapping of SOCS1 and SOCS2 to chromosomes $16 \mathrm{p} 13$ and $12 \mathrm{q}$, respectively. Genomics 61: 108-111.

26. Hölter K, Wermter AK, Scherag A, Siegfried W, Goldschmidt H, et al. (2007) Analysis of sequence variations in the suppressor of cytokine signaling (SOCS)3 gene in extremely obese children and adolescents. BMC Med Genet 8: 21 .

27. Hanada T, Kinjyo I, Inagaki-Ohara K, Yoshimura A (2003) Negative regulation of cytokine signaling by $\mathrm{CIS} / \mathrm{SOCS}$ family proteins and their roles in inflammatory diseases. Rev Physiol Biochem Pharmacol 149: 72-86.

28. Chinen T, Kobayashi T, Ogata H, Takaesu G, Takaki H, et al. (2006) Suppressor of cytokine signaling-1 regulates inflammatory bowel disease in which both IFNgamma and IL-4 are involved. Gastroenterology 130: 373-388.

29. Suzuki A, Hanada T, Mitsuyama K, Yoshida T, Kamizono S, et al. (2001) CIS3/ SOCS3/SSI3 plays a negative regulatory role in STAT3 activation and intestinal inflammation. J Exp Med 193: 471-481.

30. Shouda T, Yoshida T, Hanada T, Wakioka T, Oishi M, et al. (2001) Induction of the cytokine signal regulator SOCS3/CIS3 as a therapeutic strategy for treating inflammatory arthritis. J Clin Invest 108: 1781-1788.

31. Teofili L, Martini M, Cenci T, Guidi F, Torti L, et al. (2008) Epigenetic alteration of SOCS family members is a possible pathogenetic mechanism in JAK2 wild type myeloproliferative diseases. Int J Cancer 123: 1586-1592.

32. Matsui F, Meldrum KK (2012) The role of the Janus kinase family/signa transducer and activator of transcription signaling pathway in fibrotic renal disease. J Surg Res 178: 339-345.

33. Kuratsune M, Masaki T, Hirai T, Kiribayashi K, Yokoyama Y, et al. (2007) Signa transducer and activator of transcription 3 involvement in the development of renal interstitial fibrosis after unilateral ureteral obstruction. Nephrology (Carlton) 12: 565-571.

34. Marrero MB, Banes-Berceli AK, Stern DM, Eaton DC (2006) Role of the JAK STAT signaling pathway in diabetic nephropathy. Am J Physiol Renal Physio 290: F762-F768.

35. Yoshida T, Ogata H, Kamio M, Joo A, Shiraishi H, et al. (2004) SOCS1 is a suppressor of liver fibrosis and hepatitis-induced carcinogenesis. J Exp Med 199: 1701-1707.

36. Niwa Y, Kanda H, Shikauchi Y, Saiura A, Matsubara K, et al. (2005) Methylation silencing of SOCS-3 promotes cell growth and migration by enhancing JAK/ STAT and FAK signalings in human hepatocellular carcinoma. Oncogene 24 : 6406-6417.

37. Stevens LA, Coresh J, Greene T, Levey AS (2006) Assessing kidney function-measured and estimated glomerular filtration rate. N Engl J Med 354: 24732483.

38. Friedewald WT, Levy RI, Fredrickson DS (1972) Estimation of the concentration of low-density lipoprotein cholesterol in plasma, without use of the preparative ultracentrifuge. Clin Chem 18: 499-502.

39. Herman JG, Graff JR, Myöhänen S, Nelkin BD, Baylin SB (1996) Methylationspecific PCR: a novel PCR assay for methylation status of $\mathrm{CpG}$ islands. Proc Natl Acad Sci U S A 93: 9821-9826.

40. Fan XP, Zou ZQ, Long B, Guo YM, Wang SK, et al. (2011) Enhanced demethylation of interferon- $\hat{i}^{3}$ gene promoter in peripheral blood mononuclear cells is associated with acute-on-chronic hepatitis B liver failure. Tohoku J Exp Med 224: 13-19.

41. Chu PY, Yeh CM, Hsu NC, Chang YS, Chang JG, et al. (2010) Epigenetic alteration of the SOCS1 gene in hepatocellular carcinoma. Swiss Med Wkly 140: w13065.

42. Tokita T, Maesawa C, Kimura T, Kotani K, Takahashi K, et al. (2007) Methylation status of the SOCS3 gene in human malignant melanomas. Int $\mathrm{J}$ Oncol 30 689-694

43. Manchanda PK, Kumar A, Kaul A, Mittal RD (2006) Correlation between gene polymorphism of tumor necrosis factor-alpha $(\mathrm{G} / \mathrm{A})$ and end-stage renal disease: a pilot study from north India. Clin Chim Acta 370: 152-157.

44. Wang X, Falkner B, Zhu H, Shi H, Su S, et al. (2013) A genome-wide methylation study on essential hypertension in young African American males. PLoS One 8: e53938.

45. Gopisetty G, Ramachandran K, Singal R (2006) DNA methylation and apoptosis. Mol Immunol 43: 1729-1740.

46. Lan HY, Paterson DJ, Atkins RC (1991) Initiation and evolution of interstitia leukocytic infiltration in experimental glomerulonephritis. Kidney Int 40: 425433

47. Markó L, Kvakan H, Park JK, Qadri F, Spallek B, et al. (2012) Interferon- Î $^{3}$ signaling inhibition ameliorates angiotensin II-induced cardiac damage. Hypertension 60: 1430-1436.

48. Stokes KY, Gurwara S, Granger DN (2007) T-cell derived interferon-gamma contributes to arteriolar dysfunction during acute hypercholesterolemia Arterioscler Thromb Vasc Biol 27: 1998-2004.

49. Shoji T, Nishizawa Y, Kawagishi T, Tanaka M, Kawasaki K, et al. (1997) Atherogenic lipoprotein changes in the absence of hyperlipidemia in patients with chronic renal failure treated by hemodialysis. Atherosclerosis 131: 229236.

50. Kolovou GD, Anagnostopoulou KK, Cokkinos DV (2005) Pathophysiology of dyslipidaemia in the metabolic syndrome. Postgrad Med J 81: 358-366.

51. Johan MF, Bowen DT, Frew ME, Goodeve AC, Reilly JT (2005) Aberrant methylation of the negative regulators RASSFIA, SHP-1 and SOCS-1 in myelodysplastic syndromes and acute myeloid leukaemia. Br J Haematol 129 60-65

52. Okochi O, Hibi K, Sakai M, Inoue S, Takeda S, et al. (2003) Methylationmediated silencing of SOCS-1 gene in hepatocellular carcinoma derived from cirrhosis. Clin Cancer Res 9: 5295-5298.

53. Alexander WS, Starr R, Fenner JE, Scott CL, Handman E, et al. (1999) SOCS1 is a critical inhibitor of interferon gamma signaling and prevents the potentially fatal neonatal actions of this cytokine. Cell 98: 597-608.

54. Barrio S, Gallardo M, Albizua E, Jimenez A, Rapado I, et al. (2011) Epigenomic profiling in polycythaemia vera and essential thrombocythaemia shows low levels of aberrant DNA methylation. J Clin Pathol 64: 1010-1013.

55. Rastmanesh MM, Braam B, Joles JA, Boer P, Bluyssen HA (2009) Increased SOCS expression in peripheral blood mononuclear cells of end stage renal disease patients is related to inflammation and dialysis modality. Eur J Pharmacol 602: 163-167. 
Citation: Ghattas M, El-shaarawy F, Mesbah N, Abo-Elmatty D (2013) The Methylation Profile of IFN- $\gamma$, SOCS1 and SOCS3 Promoter Regions in End-Stage Renal Disease. J Data Mining Genomics Proteomics 4: 144. doi:10.4172/2153-0602.1000144

Page 7 of 7

56. Ortiz-Muñoz G, Martin-Ventura JL, Hernandez-Vargas P, Mallavia B, LopezParra V, et al. (2009) Suppressors of cytokine signaling modulate JAK/STATmediated cell responses during atherosclerosis. Arterioscler Thromb Vasc Bio 29: $525-531$

57. Biolo G, Amoroso A, Savoldi S, Bosutti A, Martone M, et al. (2006) Association of interferon-gamma $+874 \mathrm{~A}$ polymorphism with reduced long-term inflammatory response in haemodialysis patients. Nephrol Dial Transplant 21: 1317-1322.
58. Scherer A, Günther OP, Balshaw RF, Hollander Z, Wilson-McManus J, et al. (2013) Alteration of human blood cell transcriptome in uremia. BMC Med Genomics 6: 23.

59. Nakajima H, Takenaka M, Kaimori JY, Nagasawa Y, Kosugi A, et al. (2002) Gene expression profile of renal proximal tubules regulated by proteinuria. Kidney Int 61: 1577-1587. 